Journal of Agricultural Sciences
(Tarim Bilimleri Dergisi)

\title{
Impacts of High and Low-Input Farming Systems on the Quality Change of Safflower Oil While Intercropped with Bitter Vetch
}

\author{
Azin NAJAFABADI ${ }^{a}(\mathbb{D})$, Jalal JALILIAN" ${ }^{a *}$ \\ ${ }^{a}$ Department of Plant Production and Genetics, Faculty of Agriculture, Urmia University, Urmia, IRAN \\ ARTICLE INFO \\ Research Article \\ Corresponding Author: Jalal JALILIAN, E-mail: j.jalilian@urmia.ac.ir \\ Received: 09 January 2021; Revised: 13 July 2021 / Accepted: 14 July 2021 / Online: 01 September 2022 \\ Cite this article \\ NAJAFABADI A, JALILIAN J (2022). Impacts of High and Low-input Farming Systems on the Quality Change of Safflower oil While Intercropped with Bitter Vetch. Journal of \\ Agricultural Sciences (Tarim Bilimleri Dergisi), 28(3):401-411. DOI: 10.15832/ankutbd.857026
}

\section{ABSTRACT}

The purpose of this factorial field experiment was to investigate the influence of farming systems and intercropping patterns (IPs) on the physiological aspects of safflower and bitter vetch. Treatments included high and low-input farming systems and various IPs that exchanged safflower and bitter vetch with row ratios of 2:2, 2:3, 2:4, 2:5, while sole cropping safflower and bitter vetch were used as control. The highest grain yield of both plants was obtained from the high input farming system (HIFS). The most safflower oil yield and protein yield of bitter vetch were achieved from sole cropping in the HIFS. Safflower sole cropping in the Low-input farming system (LIFS) had the highest oil content, but in other traits, HIFS had superior to LIFS. Intercropping resulted in high $\mathrm{P}$ and $\mathrm{N}$ content and low stearic acid in safflower compared with sole cropping. These novel findings demonstrate that HIFS was beneficial than LIFS in all traits of both plants except safflower oil content and some fatty acids content like palmitic acid. Also, in the 2:2 IP monetary advantage index (MAI) and the land equivalent ratio (LER=1.13) were highest that indicating that $13 \%$ additional area needed by the sole cropping system to provide an equivalent yield in HIFS

Keywords: Fatty acid composition; Grain yield; Land equivalent ratio; Monetary advantage index; Oil and protein yield

\section{Introduction}

Conventional farming referred to as a high input system has a crucial result in enhancing food production but had a tremendous troublesome environmental impact (Lichtfouse et al. 2009). This cropping system depends on extensive inputs like pesticides and fertilizers, which produce wastes that damage the environment. Attentions have been given to finding ways to decrease restore the harmful effects of various agricultural systems. Low input farming systems help farms that utilize less out-farm inputs, integrate plant production and animal, and keep a better biotic diversity (Chaplin-Kramer et al. 2015). This farming system utilizes lower amounts of pesticides and chemical elements than the high-input farming system (Berbeć et al. 2020). So low input farming systems include exploitation techniques to obtain maximum yields without harming the health of the inhabitants and the environment (Sarkar et al. 2020).

In terms of ecology and environment, mono-cropping has a significant problem that leads to reducing soil nutrients and crop yield (Bennett et al. 2012). Compared with mono-cropping, better use of agricultural resources was observed in intercropping studies (Khan et al. 2014; Jalilian et al. 2017). Franco et al. (2015) reported that a combination of intercropping species might prepare sustainable producers and allows farmers to diminish inputs while increasing total yields. Saeidi et al. (2018) indicated that integrated use of chemical and biofertilizers in safflower/faba bean intercropping system caused to improved growth and quality of safflower.

Legumes in intercropping systems are a critical purposeful plant and are extraordinarily valuable for the agro-ecological system (Duchene et al. 2017). Bitter vetch (Vicia ervilia L.) is a grain legume, and old legume of the Mediterranean region belongs to the Fabaceae family that has been used for forage and grain production. It has a variety of positive aspect, like high yield, drought also pest's resistance, and has a protein that creates it an economically helpful supply for animal diets (GonzálezVerdejo et al. 2020). Earlier researches have explored the possibility of intercropping of legumes and non-legumes with oilseed crops to improve land productivity, economic returns, and produce quality (Cadoux et al. 2015; Zafaranieh 2015).

Safflower (Carthamus tinctorius L.) belongs to Asteraceae family is a broadleaf annual oilseed plant and acclimate to irrigated farming systems or dry land (Kohnaward et al. 2012). It was reported that safflower/fenugreek intercropping improve 
safflower oil and protein content (Abdelkader \& Hamad 2015). Zafaranieh (2015) indicated that various combinations of intercropping significantly influenced yield, yield components, and LER of safflower/chickpea in an intercropped system.

There is minor information on the impacts of various farming systems and intercropping patterns on physiological characteristics of bitter vetch and safflower. Therefore, the objective of this study was the evaluation of crop yield, protein, $\mathrm{N}$ and $\mathrm{P}$ content changes in safflower and bitter vetch and oil and fatty acid composition of safflower under low and high input intercropping farming systems.

\section{Material and Methods}

\subsection{Experimental site and meteorological data}

This field study was done at the Urmia University research farm, West Azerbaijan Province, Urmia-Iran ( $44^{\circ} 58^{\prime} \mathrm{E}, 37^{\circ} 39^{\prime} \mathrm{N}$; $1365 \mathrm{~m}$ above sea level) in 2013-2014 growing seasons. Because the weather conditions have a direct impact on the growth characteristics of the plants, therefore the mean air temperature and monthly precipitation as an experimental site weather conditions are compared with long-term averages (1985-2014) in Figure 1. The farm was deeply plowed in the past fall and early spring; disk and cultivator were done for land preparation.

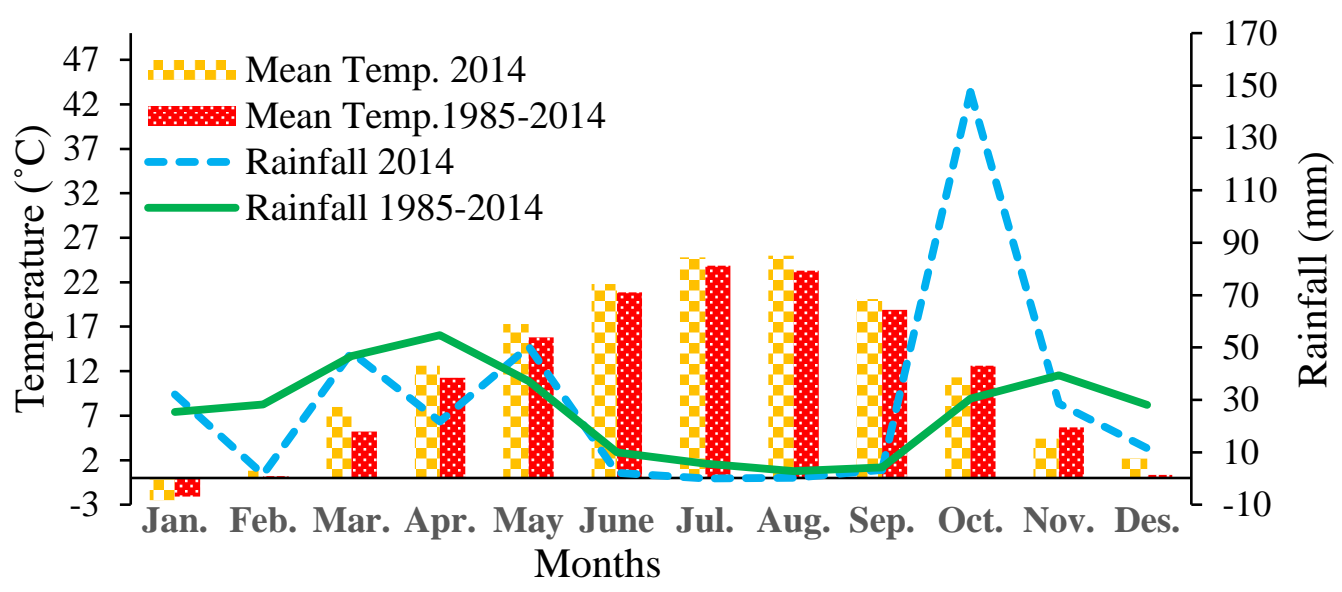

Figure 1- The mean monthly rainfall and temperature in 2014 are compared with long-term (1985-2014)

\subsection{Experimental design and crop husbandry}

Two farming systems (high and low input) and six intercropping patterns (IP) were replicated three times using a factorial experiment arranged as randomized complete block design. Intercropping patterns consist of two rows of safflower (100 $\mathrm{cm}$ wide) and various bitter vetch row ratios (two, three, four, and five rows with 50, 75, 100, and $125 \mathrm{~cm}$ wide, respectively; safflower and bitter vetch sole cropping as the control). For bitter vetch and safflower, the space between rows was 25 and 50 $\mathrm{cm}$, respectively (Figure 2).

A $30 \mathrm{~cm}$ inter-row space was allowed between bitter vetch and safflower strips, with a one-meter buffer between plots. In four respective patterns, the intercropping space ratios occupied by safflower and bitter vetch were 67\%:33\%, 57\%:43\%, 50\%:50\% and 45\%:55\%, respectively. The area of intercropping plots was 15.75, 17.5, 19.25 and $21 \mathrm{~m}^{2}$ for the four respective patterns, $10 \mathrm{~m}^{2}$ for sole bitter vetch and $15 \mathrm{~m}^{2}$ for sole safflower. At the end of April and middle of May, bitter vetch and safflower were sown by hand, respectively, in loamy clay soil (32\% clay, 37\% silt, 31\% sand) with PH 7.21 (High Input Farming System - HIFS) and 7.06 (Low Input Farming System - LIFS). 


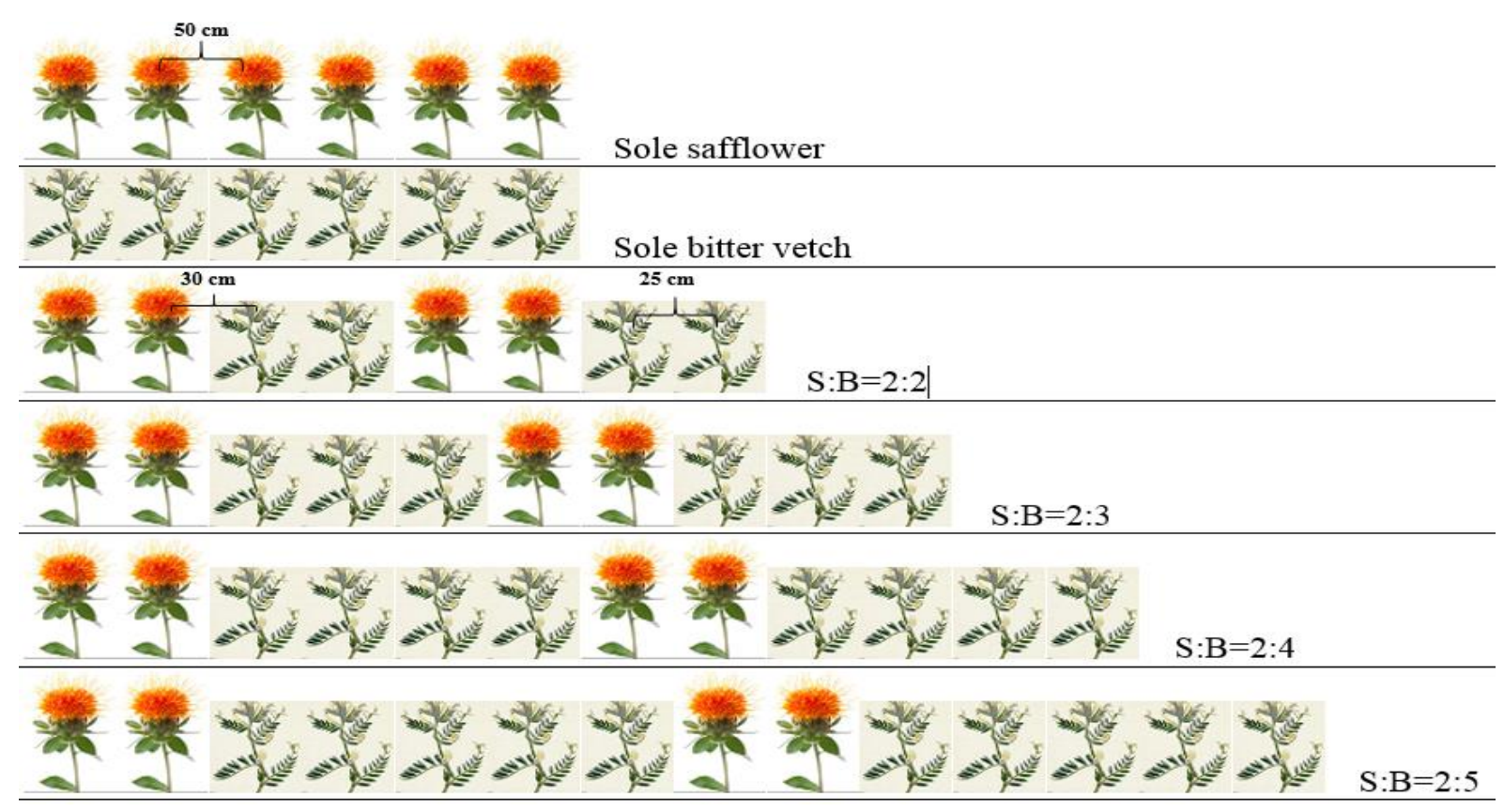

Figure 2- Graphic description of sole safflower, sole bitter vetch, and intercropping pattern between safflower (S) and Bitter vetch $(B)$

In HIFS, agronomic practices included tillage operations, shovel and rake, $120 \mathrm{~kg} \mathrm{ha}^{-1}$ urea and $90 \mathrm{~kg}^{-1}$ triple superphosphate and the Acanthiophilus helianthi Rossi and weeds chemical control, with the application of Metasystox and Gallant, respectively were done. In LIFS, weed removal was done by hand, just rake was used and $40 \mathrm{t}^{-1} \mathrm{cow}^{\mathrm{manure}}$ before planting was mixed with soil. Also, in LIFS treatment, seeds before planting inoculated with Nitroxin (Azospirillum lipoferum and Azotobacter chroococcum) and Biophosphate (Bacillus lentus, Pseudomonas putida) suspensions bacteria at $10^{9} \mathrm{CFU}^{-1}$ for 30 min (Ozturk et al. 2003). All plants were irrigated uniformly between 7 to 9 days depending on weather temperature.

\subsection{Measurements}

Safflower grain oil content was determined using a soxhlet fat extraction method by AOAC methods (AOAC 2000). By multiplying the oil content in grain yield, oil yield was obtained and expressed in kilograms per hectare $\left(\mathrm{kg} \mathrm{ha}^{-1}\right)$. Determination of fatty acids composition in safflower seeds was done according to the method of Metcalfe et al. (1966) using an Agilent gas chromatograph (a capillary column, BPX 70, $50 \mathrm{~m}$ by $0.25 \mathrm{~mm}$ with an FID detector and the carrier gas was nitrogen and hydrogen). Grain nitrogen content was measured using the Kjeldahl method. By multiplying the protein percentage in the grain yield, protein yield was obtained and expressed in kilograms per hectare $\left(\mathrm{kg} \mathrm{ha}^{-1}\right)$. The vanadate-molybdate yellow color method was used to measure grain phosphorus percentage (Chapman et al. 1961). To determine the grain yield for each plot, two lateral rows and half a meter from the beginning and the ends were ignored, and the grain yield was determined from one square meter. The index for measure the intercropping advantage, the land equivalent ratio (LER) calculated from grain yield as follows (Fetene 2003):

$\mathrm{LER}=\mathrm{Yis} / \mathrm{Yss}+\mathrm{Yib} / \mathrm{Ysb}$

Where; Yis, Yss, Yib and Ysb are the yield of intercropping and sole cropping of safflower and bitter vetch, respectively.

To compute the economic advantage, Banik et al. (2000) introduced the monetary advantage index (MAI). MAI was calculated as follows:

$\mathrm{MAI}=[(\mathrm{Yis} \times \mathrm{Ps})+(\mathrm{Yib} \times \mathrm{Pb})] \times\left(\frac{\mathrm{LER}-1}{\mathrm{LER}}\right)$

Where: Yis and Yib are the yield of intercropping of safflower and bitter vetch; $\mathrm{Ps}$ and $\mathrm{Pb}$ are the price of safflower and bitter vetch, respectively. LER is land equivalent ratio. Guaranteed purchase price in Iran for safflower and bitter vetch seeds in 2020 were $100000 \operatorname{IRR}(=0.5 \$)$ and $150000 \operatorname{IRR}(=0.75 \$)$ per kilogram, respectively.

\subsection{Statistical analysis}

The statistical analysis system (SAS Institute 2003) was used for the analysis of variance. Duncan's multiple-compare range test used for means comparison at $1 \%$ level. 


\section{Results and Discussion}

A significant effect of treatment interaction was shown for safflower oil content and oil yield (Table 1).

Table 1- Analysis of variance (mean square) for some physiological characteristics and grain yield of safflower/bitter vetch intercropping affected by different farming systems

\begin{tabular}{lllllllll}
\hline Safflower & & $\begin{array}{l}\text { Oil } \\
\text { content }\end{array}$ & $\begin{array}{l}\text { Oil } \\
\text { yield }\end{array}$ & $\begin{array}{c}N \\
\text { content }\end{array}$ & $\begin{array}{l}\text { Protein } \\
\text { content }\end{array}$ & $\begin{array}{l}\text { Protein } \\
\text { yield }\end{array}$ & $\begin{array}{c}P \\
\text { content }\end{array}$ & $\begin{array}{l}\text { Grain } \\
\text { yield }\end{array}$ \\
\hline Source of variation & $\mathrm{df}$ & & & & & & & \\
\hline Replication & 2 & $0.37^{\mathrm{ns}}$ & $4030.6^{* *}$ & $0.00056^{\mathrm{ns}}$ & $0.021^{\mathrm{ns}}$ & $1241.8^{* *}$ & $0.000^{\mathrm{ns}}$ & $396.55^{* *}$ \\
FS & 1 & $93.35^{* *}$ & $247335.5^{* * *}$ & $0.056^{* *}$ & $2.19^{* *}$ & $473461^{* *}$ & $0.007^{* *}$ & $69153.3^{* *}$ \\
IP & 4 & $32.76^{* *}$ & $373285.3^{* *}$ & $0.36^{* *}$ & $14.09^{* *}$ & $234110^{* *}$ & $0.000008^{\text {ns }}$ & $39358.6^{* *}$ \\
FS $\times$ IP & 4 & $2.07^{* *}$ & $3329^{* *}$ & $0.00049^{\text {ns }}$ & $0.019^{\text {ns }}$ & $12483^{* *}$ & $0.000005^{\text {ns }}$ & $1309.01^{* *}$ \\
Error & 18 & 0.22 & 536.5 & 0.0043 & 0.016 & 142.5 & 0.0007 & 33.31 \\
\hline Coefficient of variation $(\%)$ & 1.77 & 3.13 & 0.61 & 0.61 & 1.97 & 1.06 & 2.09 \\
\hline Bitter vetch & & & & & & & & \\
\hline Replication & 2 & - & - & $0.005^{\mathrm{ns}}$ & $4.81^{\mathrm{ns}}$ & $373.8^{\mathrm{ns}}$ & $0.0000006^{\mathrm{ns}}$ & $6.13^{\mathrm{ns}}$ \\
FS & 1 & - & - & $1.44^{* *}$ & $87.34^{* *}$ & $83029^{* *}$ & $0.0017^{* *}$ & $6912.6^{* *}$ \\
IP & 4 & - & - & $0.09^{* *}$ & $9.51^{*}$ & $170584^{* *}$ & $0.00002^{\mathrm{ns}}$ & $29306^{* *}$ \\
FS $\times$ IP & 4 & - & - & $0.004^{\mathrm{ns}}$ & $3.24^{\mathrm{ns}}$ & $5399.1^{* *}$ & $0.000001^{\mathrm{ns}}$ & $517.78^{* *}$ \\
Error & 18 & - & - & 0.004 & 3.03 & 442.7 & 0.0000015 & 10.12 \\
\hline Coefficient of variation $(\%)$ & - & - & 1.92 & 8.02 & 8.15 & 0.66 & 2.73 \\
\hline
\end{tabular}

$\mathrm{ns}, *$ and $* *$ : not significant, significant at 0.05 and 0.01 probability level, respectively. $\mathrm{FS}=\mathrm{Farming}$ system, IP=Intercropping patterns.

\subsection{Oil content and oil yield of safflower}

The most oil content of safflower with a significant difference with other treatments was observed in sole cropping located in LIFS. This value was $9.19 \%$ higher than sole cropping in HIFS (Table 2). Mean comparison showed that the highest oil yield of safflower was achieved from sole cropping in HIFS. Also, in LIFS, sole cropping was the most effective in oil yield than other IPs (Table 2). Oil yield in sole cropping of HIFS was $18.95 \%$ more than the same pattern in LIFS (Table 2).

Table 2-Mean compares some physiological characteristics and grain yield of safflower and bitter vetch affected by farming systems and different intercropping patterns

\begin{tabular}{|c|c|c|c|c|c|c|c|}
\hline \multirow[b]{2}{*}{$F S$} & \multirow[b]{2}{*}{$I P$} & \multicolumn{4}{|l|}{ Safflower } & \multicolumn{2}{|l|}{ Bitter vetch } \\
\hline & & $\begin{array}{l}\text { Oil content } \\
(\%)\end{array}$ & $\begin{array}{l}\text { Oil yield } \\
\left(K g h a^{-1}\right)\end{array}$ & $\begin{array}{l}\text { Protein yield } \\
\left(K g h a^{-1}\right)\end{array}$ & $\begin{array}{l}\text { Grain yield } \\
\left(K g h a^{-1}\right)\end{array}$ & $\begin{array}{l}\text { Protein yield } \\
\left(K g h a^{-1}\right)\end{array}$ & $\begin{array}{l}\text { Grain yield } \\
\left(K g h a^{-1}\right)\end{array}$ \\
\hline \multirow{6}{*}{ 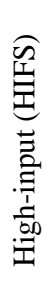 } & SS & $28.16 \pm 0.65 \mathrm{c}$ & $1188.39 \pm 44.4 \mathrm{a}$ & $834.96 \pm 17.9 \mathrm{~b}$ & $4220.14 \pm 93.7 \mathrm{a}$ & - & - \\
\hline & $2: 2$ & $22 \pm 0.10 \mathrm{f}$ & $833.8 \pm 4.9 \mathrm{~b}$ & $1025.78 \pm 5.1 \mathrm{a}$ & $3790.02 \pm 8.9 b$ & $139.1 \pm 22.5 f$ & $590.75 \pm 64.2 \mathrm{f}$ \\
\hline & $2: 3$ & $23.66 \pm 0.38 \mathrm{e}$ & $811.72 \pm 14 \mathrm{c}$ & $775.62 \pm 23 \mathrm{c}$ & $3430.8 \pm 110 \mathrm{c}$ & $196.6 \pm 4.5 \mathrm{e}$ & $840.22 \pm 21.8 \mathrm{e}$ \\
\hline & $2: 4$ & $22.58 \pm 0.48 \mathrm{f}$ & $634.58 \pm 18.8 \mathrm{~d}$ & $625.51 \pm 19 \mathrm{e}$ & $2810.4 \pm 102 \mathrm{f}$ & $256.81 .95 \mathrm{~d}$ & $1110.1 \pm 22.5 \mathrm{~d}$ \\
\hline & $2: 5$ & $27.3 \pm 0.36 \mathrm{c}$ & $524.26 \pm 22.8 \mathrm{f}$ & $386.73 \pm 10.7 \mathrm{~h}$ & $1920.4 \pm 62.4 \mathrm{~h}$ & $317.9 \pm 10.5 \mathrm{c}$ & $1390.2 \pm 39.2 \mathrm{c}$ \\
\hline & SB & - & - & - & - & $642.9 \pm 12.9 \mathrm{a}$ & $2620.6 \pm 39.1 \mathrm{a}$ \\
\hline \multirow{6}{*}{ 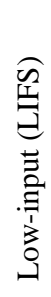 } & SS & $31.01 \pm 0.79 \mathrm{a}$ & $961.52 \pm 57.3 b$ & $592.92 \pm 19.3 f$ & $3100.7 \pm 106 \mathrm{~d}$ & - & - \\
\hline & $2: 2$ & $27.31 \pm 0.36 \mathrm{c}$ & $734.69 \pm 9.7 \mathrm{c}$ & $666.95 \pm 7.1 \mathrm{~d}$ & $2690.2 \pm 40.3 \mathrm{e}$ & $90.8 \pm 7.7 \mathrm{~g}$ & $440.67 \pm 25.5 \mathrm{~g}$ \\
\hline & $2: 3$ & $27.33 \pm .037 \mathrm{c}$ & $587.62 \pm 34.9 \mathrm{e}$ & $437.94 \pm 21.3 \mathrm{~g}$ & $2150.1 \pm 105 \mathrm{~g}$ & $129.7 \pm 1.27 f$ & $630.67 \pm 6.1 \mathrm{f}$ \\
\hline & $2: 4$ & $26.23 \pm 0.58 \mathrm{~d}$ & $461.8 \pm 20.8 \mathrm{~g}$ & $385.34 \pm 8.9 \mathrm{~h}$ & $1760.6 \pm 42.6 \mathrm{i}$ & $177.08 \pm 1.23 \mathrm{e}$ & $880.08 \pm 11.1 \mathrm{e}$ \\
\hline & $2: 5$ & $29.46 \pm 0.41 b$ & $412.49 \pm 27.4 \mathrm{~h}$ & $273.19 \pm 13.9 \mathrm{i}$ & $1400.2 \pm 75.5 \mathrm{j}$ & $182.06 \pm 6.4 \mathrm{e}$ & $1080.1 \pm 24 d$ \\
\hline & SB & - & - & - & - & $447.6 \pm 58.6 \mathrm{~b}$ & $2000.6 \pm 12 b$ \\
\hline
\end{tabular}

Values are Mean \pm Standard deviation; SD: The same letters in each column show non-significant difference at P $\leq 0.05$ by Duncan test; SS and SB: means safflower and bitter vetch sole cropping, respectively; FS: Farming system; IP: Intercropping patterns.

Safflower sole cropping in LIFS and HIFS had the highest oil content and oil yield, respectively. High oil yield in sole cropping was due to high grain yield in this intercropping pattern (Table 2). Since the oil content is negatively correlated with $\mathrm{N}$ fertilizer rate, in LIFS, due to less nitrogen availability than HIFS, the amount of oil was higher than HIFS. It is possible that in HIFS, more nitrogen resources were available for plants than organic fertilizers (Nitroxin, Biophosphate and cow manure). This reverse relationship is often attributed to the competition between oil and protein concentrations in grain for carbon skeletons throughout carbohydrate metabolism (Rathke et al. 2005). Similar results in increasing the oil content of sesame in the application 
of organic fertilizers compared to chemical fertilizers have been reported (Ratna et al. 2015). It has been reported that excessive use of nitrogen fertilizers caused a decrease in the availability of carbohydrates for oil synthesis (Rathke et al. 2005).

In sole cropping, due to the absence of bitter vetch that is a weaker competitor than safflower in nitrogen absorption, the amount of available nitrogen was less than mixed patterns; hence, the oil content in this pattern was more than IPs. Considering the beneficial properties of safflower oil and its application in traditional medicine, production of organic oil that is free of chemicals is essential. The production of good oil content is one of the main goals of oilseeds cultivation in low-input agriculture, a goal that has been achieved in this experiment (Table 2). Abdelkader \& Hamad (2015) also concluded that intercropping of safflower with fenugreek reduced amount of grain oil than sole cropping. Nasim et al. (2012) reported that nitrogen is the essential element to improve grain oil content, however, additional nitrogen rates reduced seed oil percentage and improved sunflower seed yield.

\subsection{Fatty acids composition of safflower seeds}

Variance analysis showed that the main effect of farming systems and intercropping patterns was significant on palmitic and linolenic acid content. Safflower stearic, oleic and linoleic acid were affected by the interaction of treatments (Table 3).

Table 3-Analysis of variance (mean square) for fatty acids composition of safflower intercropped with bitter vetch affected by different farming systems

\begin{tabular}{|c|c|c|c|c|c|c|}
\hline Source of variation & $d f$ & Palmitic acid & Stearic acid & Oleic acid & Linoleic acid & Linolenic acid \\
\hline Replication & 2 & $0.069^{\mathrm{ns}}$ & $0.036^{\text {ns }}$ & $0.007^{\mathrm{ns}}$ & $0.53^{\text {ns }}$ & $0.59^{\text {ns }}$ \\
\hline FS & 1 & $2.8^{*}$ & $0.5^{\mathrm{ns}}$ & $0.031^{\mathrm{ns}}$ & $113.33^{* *}$ & $2.43^{*}$ \\
\hline IP & 4 & $1.76^{* *}$ & $0.01^{*}$ & $5.45^{* *}$ & $35.96^{* *}$ & $3.38^{* *}$ \\
\hline $\mathrm{FS} \times \mathrm{IP}$ & 4 & $0.39^{\mathrm{ns}}$ & $0.86^{\text {** }}$ & $1.05^{*}$ & $16.45^{* *}$ & $0.3^{\mathrm{ns}}$ \\
\hline Error & 18 & 0.34 & 0.23 & 0.26 & 1.55 & 0.31 \\
\hline Coefficient of variation (\%) & & 11.18 & 10.3 & 5.53 & 1.94 & 14.2 \\
\hline
\end{tabular}

ns, * and **: not significant, Significant at 0.05 and 0.01 probability level, respectively; FS: Farming system; IP: Intercropping patterns

Results in Table 4 show that sole cropping had the most palmitic acid content but it's a difference with 2:2, 2:3, and 2:5 IPs were not significant. The 2:4 IP with the lowest palmitic acid content, contributed to improving the quality of produced oil in comparison with sole cropping and other IPs (Table 4). Results of mean comparison indicated that plants in HIFS had more palmitic acid than plants located in LIFS (Table 4). According to the mean comparison, HIFS had the most linolenic acid content than LIFS (Table 4).

Table 4-Palmitic and Linolenic acid percentage of safflower seeds affected by farming systems and intercropping patterns

\begin{tabular}{lll}
\hline Farming systems & Palmitic acid $(\%)$ & Linolenic acid $(\%)$ \\
\hline High- input (HIFS) & $5.56 \pm 0.81 \mathrm{a}$ & $4.25 \pm 1.02 \mathrm{a}$ \\
Low- input (LIFS) & $4.95 \pm 0.61 \mathrm{~b}$ & $3.68 \pm 0.78 \mathrm{~b}$ \\
\hline Intercropping patterns (IP) & & \\
\hline SS & $5.62 \pm 0.96 \mathrm{a}$ & $3.02 \pm 0.38 \mathrm{~d}$ \\
$2: 2$ & $5.41 \pm 0.80 \mathrm{a}$ & $3.57 \pm 0.46 \mathrm{~cd}$ \\
$2: 3$ & $5.48 \pm 0.37 \mathrm{a}$ & $3.91 \pm 0.93 \mathrm{bc}$ \\
$2: 4$ & $4.29 \pm 0.36 \mathrm{~b}$ & $5.01 \pm 0.48 \mathrm{a}$ \\
$2: 5$ & $5.48 \pm 0.54 \mathrm{a}$ & $4.31 \pm 0.86 \mathrm{~b}$ \\
\hline
\end{tabular}

Values are Mean \pm Standard deviation; SD: The same letters in each column show the non-significant difference at $\mathrm{P} \leq 0.05$ by the Duncan test; SS and SB: mean safflower and bitter vetch sole cropping, respectively.

Also, the results showed that 4:2 IP with a significant difference with other IPs had the highest amount of linolenic acid (Table 4). Our results showed that the 2:4 IP and LIFS had significantly reduced palmitic acid than other treatments (Table 4). The results showed that LIFS with the application of organic and biological fertilizer had $10.97 \%$ lower palmitic acid content than HIFS (Table 4). Therefore, LIFS reduced the harmful saturation fatty acid content in safflower oil. It has been reported that organic fertilizers reduce palmitic and stearic acid in safflower compared with chemical fertilizers (Onemli 2014). In another experiment, the reduction of palmitic fatty acids due to the application of organic fertilizers than chemicals were reported (Akbari et al. 2011). Results indicated that linolenic acid had the highest content in HIFS and 2:4 IP (Table 3). Although Linolenic acid content in HIFS was $13 \%$ higher than LIFS, nevertheless non-chemical use increased the quality of products and health of consumers and this advantage compensates for the high percentage of this fatty acid in HIFS (Table 4).

The results of the mean comparison showed that sole cropping in HIFS had the highest amount of stearic acid and its difference with the 2:2 intercropping pattern in the HIFS and 2:2, 3:2, 4:2 and 5:2 IPs in LIFS was not significant (Table 5). 
Table 5-Fatty acid percentage of safflower affected by farming systems and intercropped with bitter vetch

\begin{tabular}{|c|c|c|c|c|}
\hline Farming systems & Intercropping patterns & Stearic acid (\%) & Oleic acid $(\%)$ & Linoleic acid (\%) \\
\hline \multirow{5}{*}{$\begin{array}{l}\text { High- input } \\
\text { (HIFS) }\end{array}$} & SS & $5.68 \pm 0.31 \mathrm{a}$ & $11.35 \pm 0.43 \mathrm{a}$ & $62.31 \pm 0.57 \mathrm{de}$ \\
\hline & $2: 2$ & $5.03 \pm 0.59 \mathrm{abc}$ & $9.44 \pm 0.49 \mathrm{cde}$ & $65.28 \pm 1.9 b c$ \\
\hline & $2: 3$ & $4.59 \pm 0.58 \mathrm{bcd}$ & $8.51 \pm 0.68 \mathrm{ef}$ & $66.5 \pm 2.1 b c$ \\
\hline & $2: 4$ & $4.51 \pm 0.36 \mathrm{bcd}$ & $8.56 \pm 0.11 \mathrm{def}$ & $69.25 \pm 1.07 \mathrm{a}$ \\
\hline & $2: 5$ & $4.36 \pm 0.08 \mathrm{cde}$ & $9.01 \pm 0.73 \mathrm{cdef}$ & $66.8 \pm 0.6 b$ \\
\hline \multirow{5}{*}{$\begin{array}{l}\text { Low- input } \\
\text { (LIFS) }\end{array}$} & SS & $3.88 \pm 0.59 \mathrm{de}$ & $10.43 \pm 0.23 b$ & $62.05 \pm 0.13 \mathrm{e}$ \\
\hline & $2: 2$ & $5.2 \pm 0.75 \mathrm{abc}$ & $9.83 \pm 0.84 b c$ & $60.13 \pm 1.7 \mathrm{e}$ \\
\hline & $2: 3$ & $4.97 \pm 0.41 \mathrm{abc}$ & $9.55 \pm 0.36 \mathrm{bcd}$ & $64.35 \pm 0.49 \mathrm{~cd}$ \\
\hline & $2: 4$ & $4.97 \pm 0.32 \mathrm{abc}$ & $8.68 \pm 0.11 \mathrm{def}$ & $64.35 \pm 1.08 \mathrm{~cd}$ \\
\hline & $2: 5$ & $5.31 \pm 0.09 \mathrm{ab}$ & $8.14 \pm 0.24 \mathrm{f}$ & $57.88 \pm 0.41 \mathrm{f}$ \\
\hline
\end{tabular}

Values are Mean \pm Standard deviation; SD: The same letters in each column show non-significant difference at $\mathrm{P} \leq 0.05$ by Duncan test; SS: means safflower sole cropping

The mean comparison showed that sole cropping of safflower in HIFS had the highest amount of oleic acid, with a significant difference from other treatments (Table 5). Generally, in both farming systems, sole cropping had the highest percentage of oleic acid (Table 5). The mean comparison results showed that the maximum amount of linoleic acid was achieved from 2:4 IP in HIFS, which statistically had a significant difference with other treatments in this experiment (Table 5). The lowest amount of stearic acid belonged to the sole cropping located in LIFS which was $31.69 \%$ lower than sole cropping in HIFS but it's the difference with 2:3, 2:4 and 2:5 IPs in HIFS was not significant (Table 5). Our results have shown that the amount of oleic acid in the sole cropping of HIFS was $8.1 \%$ more than the similar pattern in LIFS (Table 5). There is a significant negative relationship between linoleic and oleic acid content so that when the value of one decrease, the value of the other increases, as evident in this experiment (Table 5).

\subsection{Grain nitrogen, protein content and protein yield}

Means comparison showed that safflower and bitter vetch grains had the most nitrogen and protein content in HIFS (Figure 3). The most nitrogen and protein content of safflower and bitter vetch grains were obtained in a high input farming system (Figure 3).

In HIFS, more availability of $\mathrm{N}$ and $\mathrm{P}$ caused improvement in some physiological traits (Figures 3, 4, 5 and Tables 2, 4 and 5).
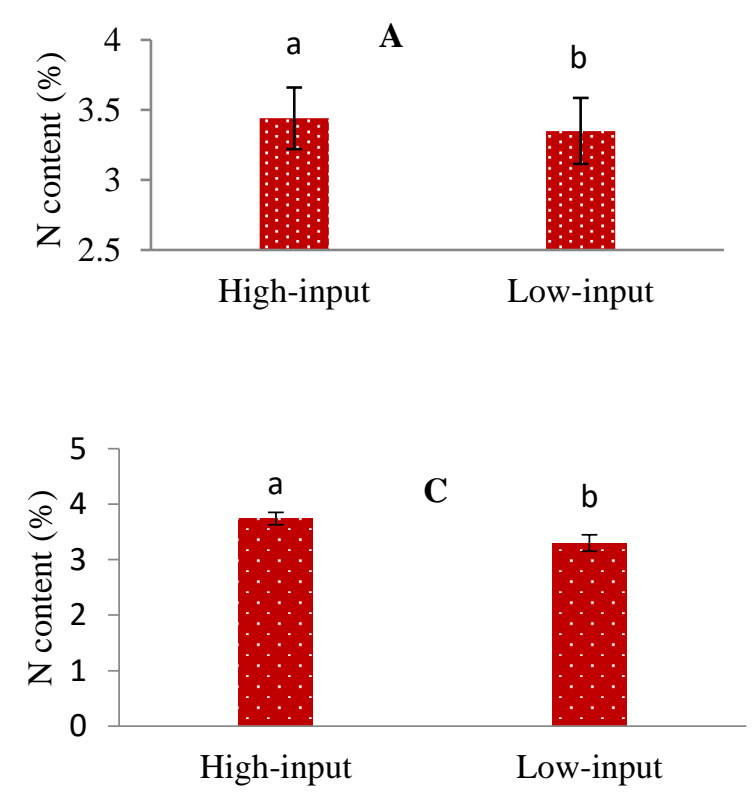

Figure 3- Mean ( \pm Standard deviation, SD) comparison for safflower nitrogen (A), protein content (B) and bitter vetch nitrogen $(C)$, protein content $(D)$ influenced by farming systems. Error bars show standard errors of the mean. The same letters show the non-significant difference at $P \leq 0.05$ by the Duncan test

Since nitrogen is the main component of proteins, Nitrogen fertilizer can increase the nitrogen and subsequently protein content of grains. It has been reported that a sufficient amount of phosphorus also affects RNA synthesis, which increases protein synthesis (Raven 2013). A large part of plant nitrogen participates in rubisco structure after performing its photosynthesis role during plant growth, in the leave's senescence with chlorophyll degradation, nitrogen is removed from the structure of rubisco 
and transferred to the growing grains and is eventually used during the synthesis of protein in seeds (Li et al. 2020). Figure 3B shows that all IPs, especially 2:2 IP, have superiority to sole cropping of safflower and this shows advantages of intercropping in protein content improvement. The availability of suitable nitrogen concentration and less competitive ability of bitter vetch in 2:2 IP caused the more generous amount of nitrogen and protein.

The most protein and nitrogen content of safflower grains were obtained from 2:2 IP, and the lowest were observed in sole cropping (Figure 4A and B). In bitter vetch, sole cropping had the highest seed protein and nitrogen (Figure 4C and D).
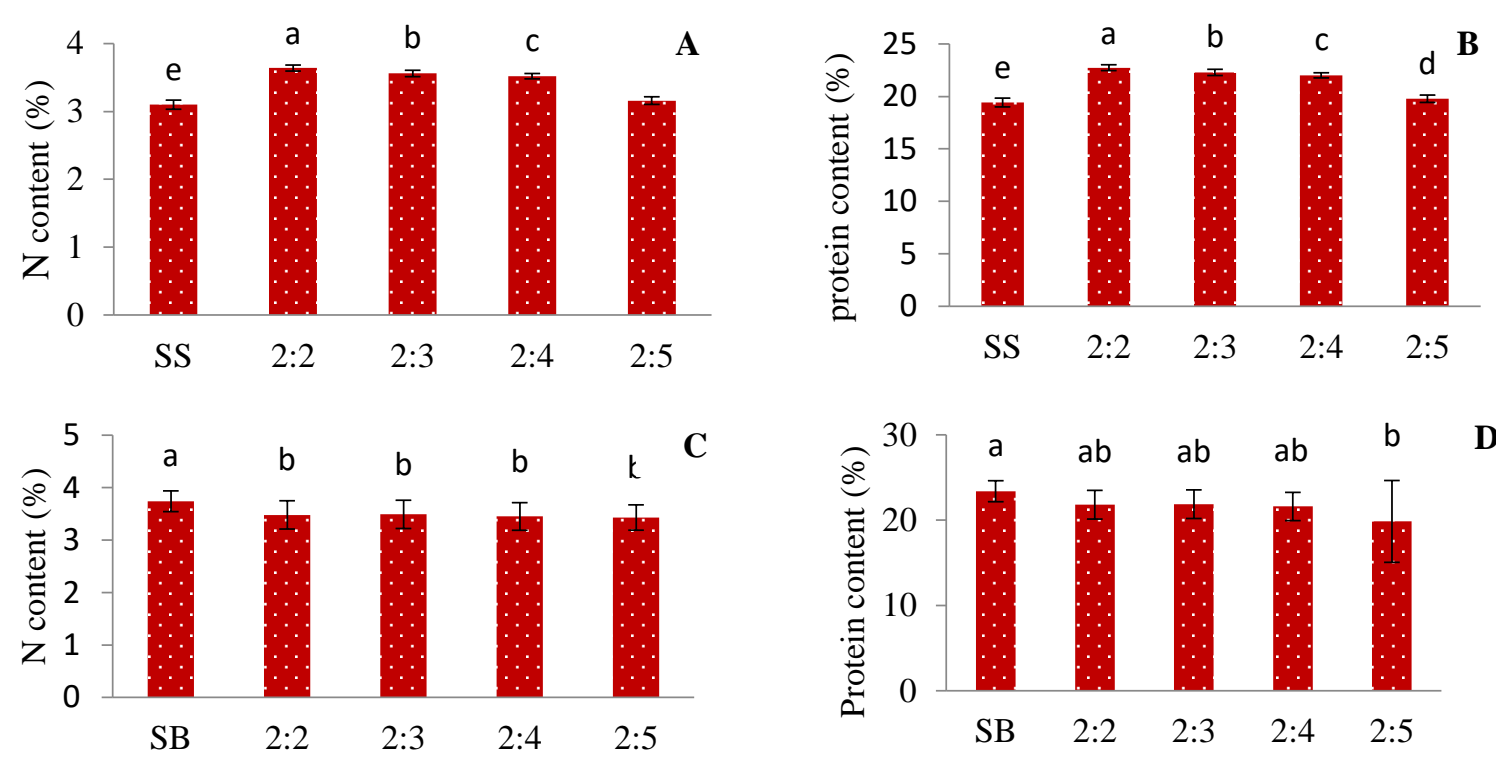

Figure 4- Mean ( \pm Standard deviation, SD) comparison for safflower nitrogen (A), protein content (B) and bitter vetch nitrogen $(C)$, protein content $(D)$ influenced by different intercropping patterns. Error bars show standard errors of the mean. The same letters show non-significant difference at $\mathbf{P} \leq \mathbf{0 . 0 5}$ by the Duncan test. SS and SB mean safflower and bitter vetch sole cropping, respectively

The high nitrogen and protein content of bitter vetch in sole cropping may be associated with a lack of safflower in this pattern. Since safflower is a more competitive plant than bitter vetch, in sole cropping of bitter vetch, more nitrogen and phosphorus are available for this plant with less competition. Because safflower has higher competitive abilities like more extensive shoot and root compared with bitter vetch, it was dominant in competition. According to the results mentioned, bitter vetch had the most protein content (Figure 4D) and seed yield in sole cropping under HIFS (Table 2). Therefore, this treatment was effective in increasing protein yield.

The mean comparison showed that 2:2 IP in HIFS had the highest protein yield in safflower, which its difference with other IPs was significant. In both HIFS and LIFS, safflower had the highest protein yield in the 2:2 IP (Table 2).

High protein content in 2:2 IP (Figure 4B) caused high protein yield in this pattern (Table 2). In bitter vetch, the most protein yield was observed in sole cropping in HIFS, which had a significant difference with other treatments (Table 2).

\subsection{Grain yield and phosphorus content}

The mean comparison showed that, sole cropping of safflower and bitter vetch in HIFS had the highest grain yield, with a significant difference with other IPs (Table 2). Comparison between intercropping patterns showed that in both farming systems, safflower had the most grain yield at 2:2 IP (Table 2), but the maximum grain yield for bitter vetch was obtained from 2:5 intercropping pattern (Table 2). The absence of competition for resources, also the use of pest management and fertilizers, led to the highest grain yield in HIFS for sole cropping of bitter vetch (Table 2). Yield reduction at IPs may be arising from competition for water, nutrients and solar radiation compared with sole cropping (Belel et al. 2014). Because of more input usage, the total yield of both plants increased in HIFS Compared to LIFS (Table 2). The sole cropping of safflower for each system yielded more than the entire bitter vetch: safflower intercropping. High grain yield in sole cropping pattern of safflower and the superiority of the IPs can be justified by land equivalent ratio (LER) Index. The grain yield of safflower was higher than bitter vetch. The facilitative influence of bitter vetch can offer nitrogen through symbiotic nitrogen fixation that successively reduces the overburden pressure on soil nitrogen sources. In sole cropping of bitter vetch, access to inputs may increase yield. Decreasing grain yield in the LIFS compare with HIFS may be due to low access to nutrients by plants, especially nitrogen and phosphorus, when plants require elements. It has been reported that nitrate and ammonium released by organic residues cannot provide optimum nutritional requirements for plants. Thus, low input farming productivity is limited by the availability of nitrogen 
(Zarabi \& Jalali 2012). Rouphael et al. (2015) have also reported reduced Perilla grain yield by $27 \%$ in low-input farming systems than the high-input farming system.

Mean comparison indicated that in both safflower and bitter vetch, grains in both plants located in HIFS had the most phosphorus content and its difference with LIFS was significant (Figure 5A and B). High input farming system in comparison with a low input farming system increase phosphorus content in safflower and bitter vetch seeds by 14.81 and $5.26 \%$ respectively (Figure 5A and B). Gaj \& Gorski (2014) in their research, demonstrated that the application of phosphorus increased nitrogen, phosphorus, potassium, calcium and magnesium uptake in winter wheat. The type of tillage in HIFS is such that the elements in the surface layer are mixed with deep layers, but in the LIFS, the tillage was superficial, so nutrients cannot penetrate in depths and are not available for deeper roots (Cai et al. 2014).


Figure 5- Mean ( \pm Standard deviation, SD) comparison for grain phosphorus $(P)$ content of safflower (A) and bitter vetch (B) affected by farming systems. Error bars show standard errors of the mean. The same letters show non-significant difference at $\mathbf{P} \leq \mathbf{0 . 0 5}$ by the Duncan test

\subsection{Land equivalent ratio (LER)}

In Figure 6 LER data of various intercropping patterns are given. The amounts of LER for all intercropping patterns were more than one except for 2:5 IP. In both systems, the 2:2 IP had yield advantages that suggest the preference of intercropping relative to sole cropping. Results indicated that by increasing bitter vetch density, the value of LER decreased. As shown in Figure 6 only the LER of 2:5 intercropping pattern was less than one. All intercropping patterns except 5:2 in HIFS had the most amount of LER value compared with LIFS (Figure 6).

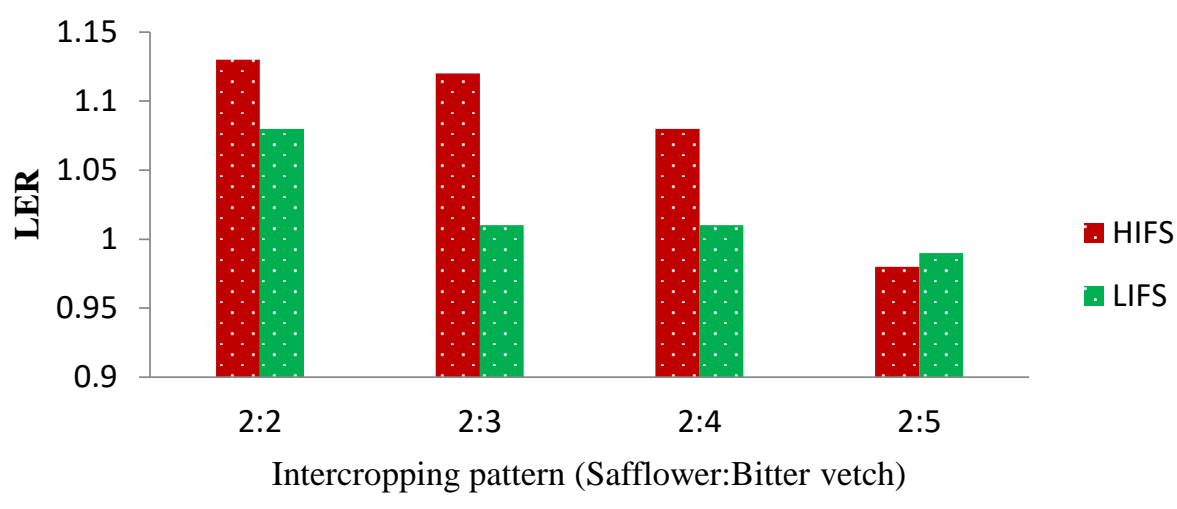

Figure 6- LER values of various intercropping patterns of safflower and bitter vetch influenced by the farming system. HIFS: High input farming system, LIFS: Low input farming system

The land equivalent ratio is mixed cropping benefits index, which indicates the degree of inter-species competition or facilitating of mixed cropping system (Fetene 2003). Land equivalent ratio more than one in mixed cropping is because of the efficient use of environmental resources, element's exchange, increasing of competitive ability of plants with weeds, nitrogen fixation by legumes, as well as differences in root system and different physiological and morphological requirements of components of mix cropping and the higher absorption of radiation (Vandermeer 1989). The productivity of intercropping than sole cropping, introduced by LER value, has been reported by many researchers (Hamdani \& Suradinata 2015 ; Metwally et al. 2015; Nyoki \& Ndakidemi 2017).

\subsection{Monetary advantage index (MAI)}

This index is the result of the value of intercropped crops and land equivalent ratio. The higher MAI value shows the more profitable (Dhima et al. 2007). In Fact, the positiveness of this index indicates the usefulness and economic advantage of 
intercropped cultivation and better use of available resources by plants compared to sole cropping of them. The results of MAI calculation (Figure 7) showed that HIFS was superior than LIFS in 2:2, 2:3 and 2:4 intercropping patterns, but in 2:5 intercropping patterns, LIFS was better than HIFS. 2:2 intercropping pattern in both HIFS and LIFS had the most MAI index than other IP (Figure 7).

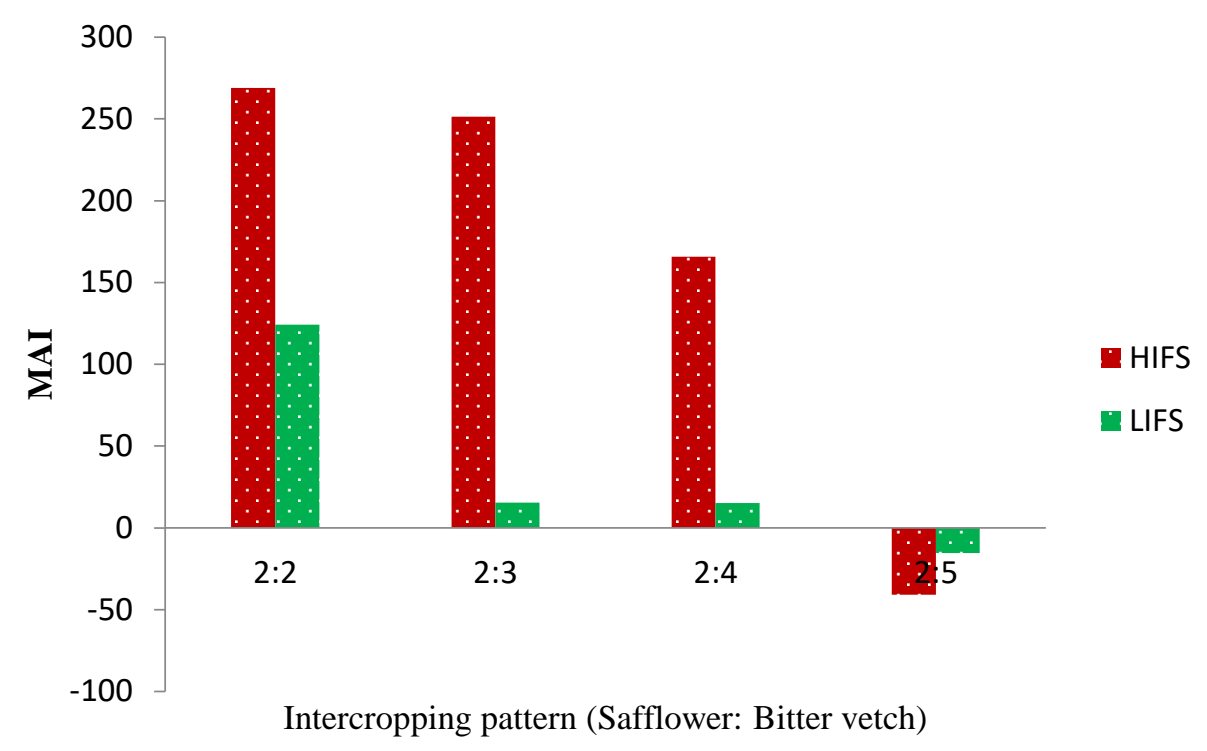

Figure 7- MAI values of various intercropping patterns of safflower and bitter vetch influenced by the farming system. HIFS: High input farming system, LIFS: Low input farming system

Khippal et al. (2016) reported that the maximum monetary advantage index in the intercropping of sugarcane with peas and recommended the implementation of this planting system in order to obtain more income for farmers. It is also reported a decrease in barley yield by using different barley and alfalfa intercropping systems, but in the treatment of 2 rows of barley +2 rows of alfalfa and 6 rows of barley +2 rows of alfalfa, due to increased alfalfa seed yield that it had a higher economic value, eventually the monetary advantage index increased (Esmaeili et al. 2011).

\section{Conclusions}

The study shows that in all traits of both safflower and bitter vetch except safflower oil content and some fatty acids content like palmitic acid, HIFS was beneficial and had a significant difference with LIFS. The characteristics of safflower were affected by intercropping patterns. In most studied traits, sole cropping was the most advantageous pattern, but in some characteristics, IPs was beneficial, especially 2:2 IP, which was superior to sole cropping. However, in all traits of bitter vetch, sole cropping was useful and this was probably due to the dominance of safflower compared to the bitter vetch. Depending on our purpose of the intercropping of these two plants, different patterns and systems are recommended. To harvest high levels of safflower protein, 2:2 IP has a better result than other mixed patterns but to achieve high oil content, sole cropping must be used. Concerning oil quality, 2:4 IP had the highest linoleic acid content which increased oil quality. Results showed that LIFS had the highest percentage of oil production. Although HIFS had higher grain yield and compensated for the low amount of oil, but the healthy product in the LIFS made it superior to HIFS. According to the results of the land equivalent ratio (LER) and monetary advantage index (MDI), the highest values of these indices were observed in 2:2 IP in HIFS and this can be the advantageous IP than other intercropping patterns.

\section{Acknowledgments}

Urmia University of Iran (Ph.D. Thesis of the first author) supported this research and we dedicate it to our late colleague Dr. Mohammad Reza Zardashti. 
Abbreviations and Symbols

$\begin{array}{ll}\text { FS } & \text { Farming systems } \\ \text { HIFS } & \text { High input farming system } \\ \text { IPs } & \text { Intercropping patterns } \\ \text { LER } & \text { Land equivalent ratio } \\ \text { LIFS } & \text { Low input farming system } \\ \text { SB } & \text { Sole cropping bitter vetch } \\ \text { SS } & \text { Sole cropping safflower } \\ \text { MAI } & \text { Monetary advantage index }\end{array}$

\section{References}

Abdelkader M A I \& Hamad E H A (2015). Evaluation of productivity and competition indices of safflower and fenugreek as affected by intercropping pattern and foliar fertilization rate. Middle East Journal of Agricultural Research 4(4): 956-966

Akbari P, Ghalavand A, Sanavy A M \& Alikhani M A (2011). The effect of biofertilizers, nitrogen fertilizer and farmyard manure on grain yield and seed quality of sunflower (Helianthus annus L.). Journal of Agricultural Science and Technology 7(1): 173-184

AOAC (2000). Fatty acids in oils and fats. Official methods of analysis of the AOAC, $17^{\text {th }}$ Ed. AOAC, Arlington, Virginia USA.

Banik P, Sasmal T, Ghosal P K \& Bagchi D K (2000). Evaluation of mustard (Brassica compestris Var. Toria) and legume intercropping under 1:1 and 2:1 row-replacement series systems. Journal of Agronomy and Crop Science 185: 9-14. DOI: 10.1046/j.1439-037X.2000.00388.x

Belel M D, Halim R A, Rafii M Y \& Saud H M (2014). Intercropping of corn with some selected legumes for improved forage production: a review. Journal of Agricultural Science 6(3):48-62. DOI: 10.5539/jas.v6n3p48

Bennett A, Bending G, Chandler D, Hilton S \& Mills P (2012). Meeting the demand for crop production: the challenge of yield decline in crops grown in short rotations. Biological Reviews 87: 52-71. DOI: 10.1111/j.1469-185X.2011.00184. x.

Berbeć A K, Staniak M, Feledyn-Szewczyk B, Kocira A \& Stalenga J (2020). Organic but also low-input conventional farming systems support high biodiversity of weed species in winter cereals. Agriculture 10(9):413. DOI: 10.3390/agriculture10090413

Cadoux S, Sauzet G, Valantin-Morison M, Pontet C, Champolivier L, Céline R, Lieven J, Flénet F, Mangenot O, Fauvin P \& Landé N (2015). Intercropping frost-sensitive legume crops with winter oilseed rape reduces weed competition, insect damage, and improves nitrogen use efficiency. Oilseeds and Fats, Crops and Lipids 22(3): 1-11. DOI: 10.1051/oc1/2015014

Cai H, Ma W, X Zhangm, Ping J, Yan X, Liu J, Yuan J, Wang L \& Ren J (2014). Effect of subsoil tillage depth on nutrient accumulation, root distribution, and grain yield in spring maize. Crop Journal 2: 297-307. DOI: 10.1016/j.cj.2014.04.006

Chaplin-Kramer R, Sharp R P, Mandle L, Sin S, Johnson J, Butnar I, Mila I Canals L, Eichelberger BA, Ramler I, Mueller C, Mclacclan N, Yousefi A, king H \& Kareiva P M (2015). Spatial patterns of agricultural expansion determine impacts on biodiversity and carbon storage. Proceedings of the National Academy of Sciences of the USA 112: 7402-7407. DOI: 10.1073/pnas.1406485112

Chapman H D \& Pratt P F (1961). Method of analysis for soil, plants, and waters. University of California. Division of agricultural science. Berkeley, California, 309 p.

Dhima K V, Lithourgidis A S, Vasilakoglou I B \& Dordas C A (2007). Competition indices of common vetch and cereal intercrops in two seeding ratios. Field Crops Research 100: 249-256. DOI: 10.1016/j.fcr.2006.07.008

Duchene O, Vian J F \& Celette F (2017). Intercropping with legume for agroecological cropping systems: Complementarity and facilitation processes and the importance of soil microorganisms: a review. Agriculture, Ecosystem and Environment 240:148-161. DOI: 10.1016/j.agee.2017.02.019

Esmaeili A, Sadeghpour A, Hosseini S M B, Jahanzad E, Chaichi M R \& Hashemi M (2011). Evaluation of seed yield and competition indices for intercropped barley (Hordeum vulgare) and annual medic (Medicago scutellata). International Journal of Plant Production 5(4): 395404. DOI: 10.22069/IJPP.2012.749

Fetene M (2003). Intra-and inter-specific competition between seedlings of Acacia etbaica and a perennial grass (Hyparrenia hirta). Journal of Arid Environments 55(3): 441-451. DOI: 10.1016/S0140-1963 (03)00052-1

Franco J G, king R S, Masabni G J \& Volder A (2015). Plant functional diversity improves short-term yields in a low-input intercropping system. Agriculture, Ecosystem and Environment 203: 1-10. DOI: 10.1016/j.agee.2015.01.018

Gaj R \& Gorski D (2014). Effects of different phosphorus and potassium fertilization on contents and uptake of macronutrients (N, P, K, Ca, $\mathrm{Mg}$ ) in winter wheat I. Content of macronutrients. Journal of Central European Agriculture 15(4): 169-187. DOI: 10.5513/jcea. v15i4.2877

González-Verdejo C I, Fernández-Aparicio M, Córdoba E M \& Nadal S (2020). Identification of Vicia ervilia germplasm resistant to orobanche crenata. Plants 9(11): 1568. DOI: 10.3390/plants9111568

Hamdani J S \& Suradinata Y R (2015). Effects of row intercropping system of corn and potato and row spacing of corn on the growth and yields of Atlantic potato cultivar planted in medium altitude. Asian Journal of Agricultural Research 9(3): 104-112. DOI: 10.3923/ajar.2015.104.112

Jalilian J, Najafabadi A \& Zardashti M R (2017). Intercropping patterns and different farming systems affect the yield and yield components of safflower and bitter vetch. Journal of Plant Interactions 12: 92-99. DOI: 10.1080/17429145.2017.1294712

Khan S, Khan M A, Akmal M, Ahmad M, Zafar M \& Jabeen A (2014). Efficiency of wheat brassica mixtures with different seed rates in rainfed areas of Potohar-Pakistan. Pakistan Journal of Botany 46(2): 759-766

Khippal A, Singh S, Chand M, Sheokand R, Singh J, Verma R \& Kumar R (2016). Mechanized and profitable intercropping of legumes in autumn planted sugarcane. Legume Research 39(3): 411-418. DOI: 10.18805/lr.v0iOF.10283

Kohnaward P, Jalilian J \& Pirzad A (2012). Effect of foliar application of micro-nutrients on yield and yield components of safflower under conventional and ecological cropping systems. International Research Journal of Applied and Basic Sciences 3(7): 1460-1469

Li Y T, Li Y, Li Y N, Liang Y, Sun Q, Li G, Liu P, Zhang Z S \& Gao H Y (2020). Dynamic light caused less photosynthetic suppression, rather than more, under nitrogen deficit conditions than under sufficient nitrogen supply conditions in soybean. BMC plant biology 20(1):113. DOI: $10.1186 / \mathrm{s} 12870-020-02516-\mathrm{y}$

Lichtfouse E, Navarrete M, Debaeke P, Souchère V, Alberola C \& Ménassieu J (2009). Agronomy for sustainable agriculture: a review. Agronomy for Sustainable Development 29:1-6. DOI: 10.1051/agro:2008054 
Metcalfe L D, Schmitz A A \& Pelka J R (1966). Rapid preparation of fatty acid esters from lipid for gas chromatography analysis. Analytical Chemistry 38: 514-515. DOI: 10.1021/ac60235a044

Metwally A A, Safina S A \& Noaman A H (2015). Yield and land equivalent ratio of intercropping maize with Egyptian cotton. Journal of Agri-Food and Applied Sciences 3(4): 85-93

Nasim W, Ahmad A, Hammad H M, Chaudhary H J \& Munis M F H (2012). Effect of nitrogen on growth and yield of sunflower under semiarid conditions of Pakistan. Pakistan Journal of Botany 44(2): 639-648

Nyoki D \& Ndakidemi P A (2017). Assessing the land equivalent ratio (LER) of maize (Zea mays L.) intercropped with Rhizobium inoculated soybean (Glycine max [L.] Merr.) at various P and K levels. International Journal of Biosciences 10(3): 275-282. DOI: 10.12692/ijb/10.3.275282

Onemli F (2014). Fatty acid content of seed at different development stages in canola on different soil types with low organic matter. Plant Production Science 17(3): 253-259. DOI: 10.1626/pps.17.253

Ozturk A, Caglar O \& Sahin F (2003). Yield response of wheat and barley to inoculation of plant growth promoting rhizobacteria at various levels of nitrogen fertilization. Journal of Plant Nutrition and Soil Science 166: 262-266. DOI: 10.1002/jpln.200390038

Rathke G W, Christen O \& Diepenbrock W (2005). Effects of nitrogen source and rate on productivity and quality of winter oilseed rape (Brassica napus L.) grown in different crop rotations. Field Crops Research 94: 103-113. DOI: 10.1016/j.fcr.2004.11.010

Ratna N D, Sarwono A E \& Hariyono B (2015). The Effect of organic and inorganic fertilizer on production, sesame seed oil content, and feasibility in sandy coastal land. In: Hongladarom, S. (ed.) Food security and food safety for the twenty-first century. Springer, Singapore, pp. 119-129

Raven J A (2013). RNA function and phosphorus use by photosynthetic organisms. Frontiers in Plant Science 4: 1-13. DOI: 10.3389/fpls.2013.00536

Rouphael Y, Raimondi G, Paduano A, Sacchi R, Barbieri G \& De Pascale S (2015). Influence of organic and conventional farming on seed yield, fatty acid composition and tocopherols of Perilla. Australian Journal of Crop Science 9(4): 303-308

Saeidi M, Yaghoub R A E I, Amini R, Taghizadeh A, \& Pasban-Eslam B (2018). Changes in fatty acid and protein of safflower as response to biofertilizers and cropping system. Turkish Journal of Field Crops 23(2): 117-126. DOI: 10.17557/tjfc.471666

Sarkar D, Kar S K, Chattopadhyay A, Rakshit A, Tripathi V K, Dubey P K \& Abhilash P C (2020). Low input sustainable agriculture: A viable climate-smart option for boosting food production in a warming world. Ecological Indicators 115: 106412. 10.1016/j.ecolind.2020.106412

SAS Institute (2003). The SAS system for windows. Release 9.1. SAS Inst., Cary, NC.

Vandermeer J H (1989). The ecology of intercropping. Cambridge University Press, Cambridge 237 p. DOI: 10.1017/CBO9780511623523.

Zafaranieh M (2015). Effect of various combinations of safflower and chickpea intercropping on yield and yield components of safflower. Agriculture Science Developments 4: 31-34

Zarabi M \& Jalai M (2012). Rate of nitrate and ammonium release from organic residues. Compost Science and Utilization 20: 222-229. DOI: 1065657X.2012.10737052

(C) 2022 by the author(s). Published by Ankara University, Faculty of Agriculture, Ankara, Turkey. This is an Open Access article distributed under the terms and conditions of the Creative Commons Attribution (CC BY) license (http://creativecommons.org/licenses/by/4.0/), which permits unrestricted use, distribution, and reproduction in any medium, provided the original work is properly cited. 